Jap. J. M. Sc. \& Biol., 11, 161-168, 1958

\title{
STUDIES ON THE STREAMING TRANSPARENCY OF RED BLOOD CELL SUSPENSION
}

\section{EFFECT OF RED CELL WASHING WITH SALINE SOLUTION ON S.L.I.R. OF RED CELL SUSPENSION}

\author{
WATARU NAKAMURA*, YUJi AMADA, Toshikó JIMBO AND MASARU OTAWA \\ Department of Biological Chemistry, Yokohama University \\ School of Medicine, Yokohama
}

(Received: June 11th, 1958)

When a red cell suspension is prepared by suspending un-washed red cells, it may happen that the minute quantities of serum adhering to the cells cause an unexpectedly great change in nature of the suspension and lead to intricacy in studying the interaction between the cells and the artificial medium. By the way, a lasting effect of pretreatment of red cells with saline solution is also observed by several researchers. The irreversible change of washed red cells subjected to its hemolysability in hypo- or hypertonic saline solution, as stated by Nakamura and Kuroda (1936), Ponder (1948) etc., is a case in point. Miyake (1955) also observed the irreversible transformation of non-nucleated erythrocyte, previously washed with the saline solution.

In the study on S.L.I.R. of red cell suspension the above effect is still a matter of consideration.

\section{MATERIAL AND METHODS}

The materials and methods were unaltered from those described in the preceding paper (Nakamura and Amada, 1958) except for the following points.

Washing procedure of red cell: The red cell suspension was centrifcged for 5 minutes at 3,000 rpm at room temperature and the supernatant discarded. Packed cells thus obtained were considered as having been subjected to one washing cycle. Adequate quantities of new saline solution were poured into the tube to make a suspension of original concentration.

Microscope photographing of red cell: The suspension was introduced between a red cell counting chamber and a coverglass, both silicon-coated, and the red cells were photographed by microscope before they sank down all to the bottom.

* Present address: 9 Hiyoshi-machi, Kohoku-ku, Yokohama-city. 中村弥・天田祐治・神保卜 シ子・大多和優（横浜市大医学部生化学教室） 


\section{RESULTS}

\section{Shape of Red Cells Repeatedly Washed with 0.25 Mol Saline and S.L.I.R. of the Suspension}

The red cell suspension, prepared by suspending $0.8 \mathrm{cc}$ of red cell gruel in $200 \mathrm{cc}$ of $0.25 \mathrm{~mol} \mathrm{NaCl}$, was devided into ten portions of $20 \mathrm{cc}$. One of them was submitted to observation immediately after the preparation, and the other portions after having been subjected to several washing cycles repeatedly. The

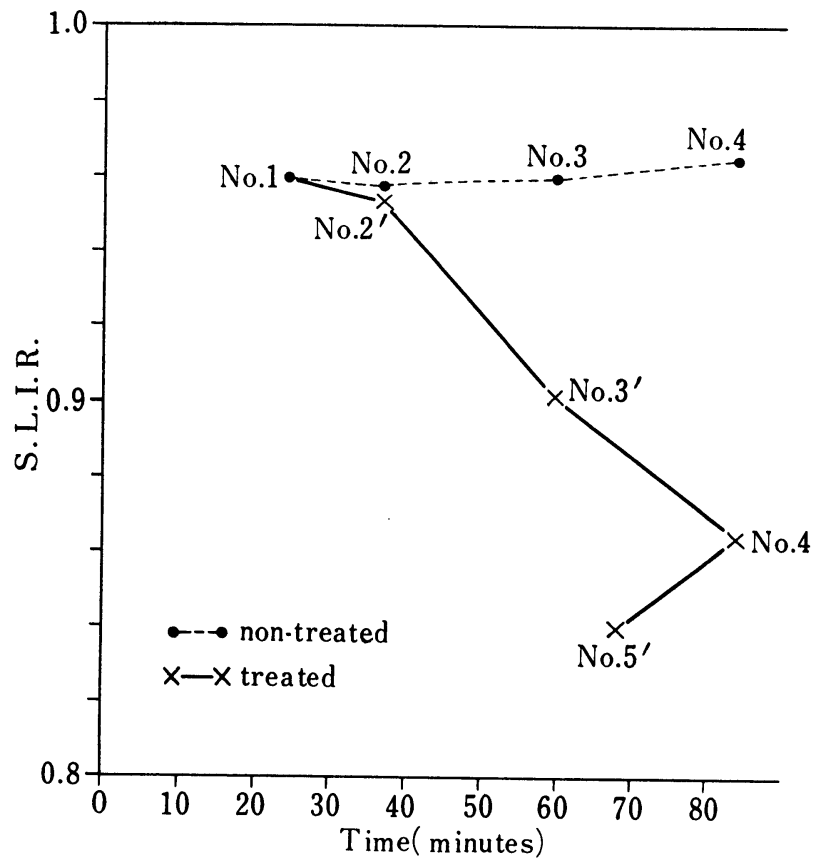

A

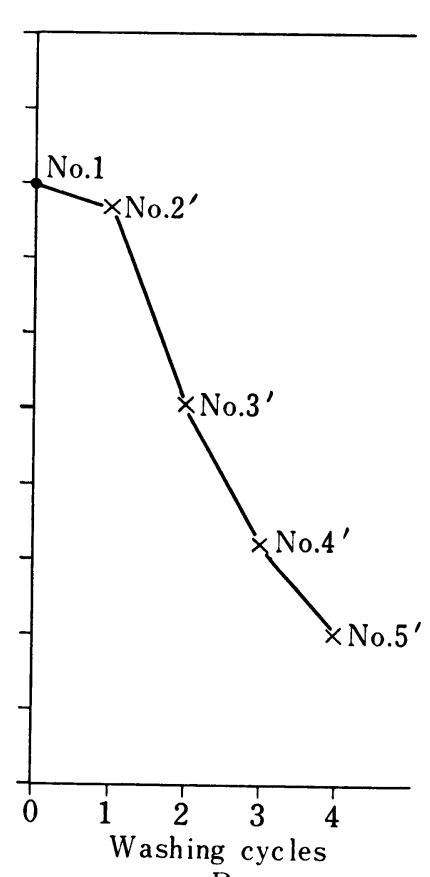

$\mathrm{B}$

Fig. 1. Effect of the previous washing of red blood cells with the saline solution $(0.25 \mathrm{~mol})$ on the S.L.I.R. of the suspension (I).

A: Duration after preparation of the suspension as ordinate.

B: Washing cycles as ordinate.

observation with the non-treated suspension was also performed as a control. The resulting data of the S.L.I.R. are presented graphically in Fig. 1 and the shapes of red cells in the corresponding suspensions are demonstrated in Fig. 2. The S.L.I.R. increases gradually as time goes on in the control, while that of the suspension containing the washed red cells decreases greatly, attaining to 0.84 after four washing cycles.

The parallelism between the S.L.I.R. and the degree of asymmetry of red cell, e.g., thorn apple form, crenated discoid and biconcave disc, is to be ascertained 


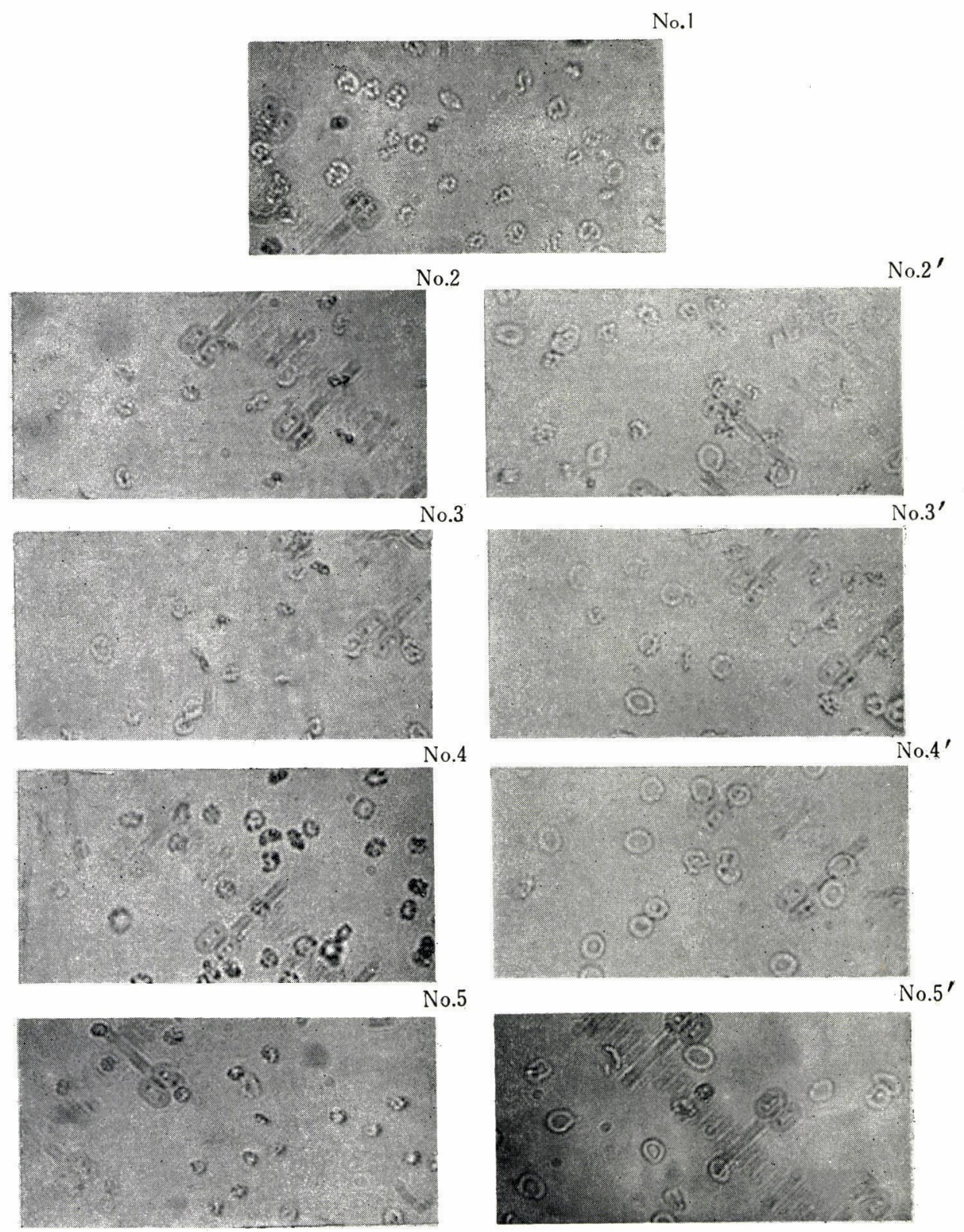

Fig. 2. Effect of washing of red cells with $0.25 \mathrm{~mol}$ saline solution on their shape.

Numbers of the photographs correspond to that of Fig. 1. 


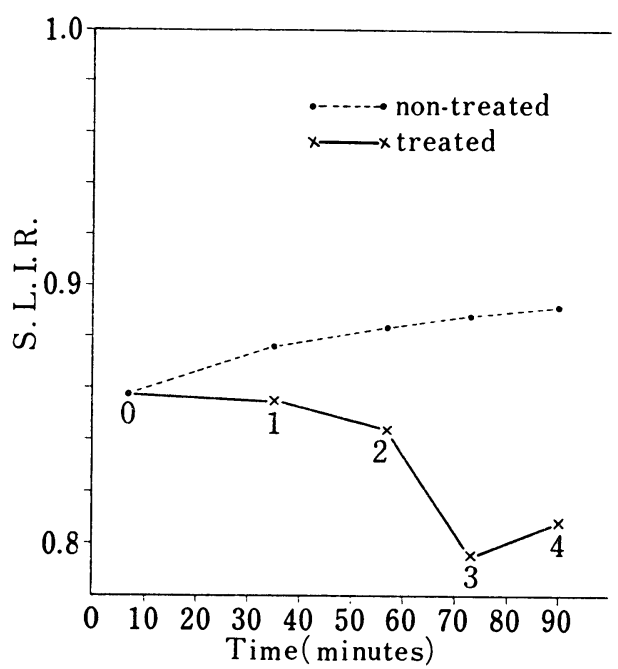

Fig. 3. Effect of the previous washing of red blood cells with the saline solution $(0.25 \mathrm{~mol})$ on the S. L. I. R. of the suspension. (II).

Figures in the graph present the frequency of washing cycle.

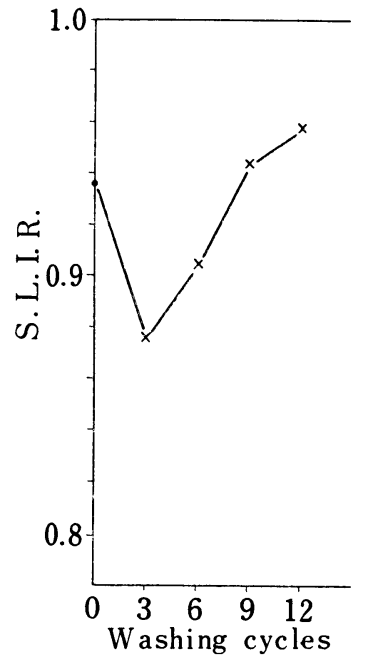

Fig. 4. Effect of the previous washing of red blood cells with the saline solution $(0.25 \mathrm{~mol})$ on the S. L. I. R. of the suspension. (III).
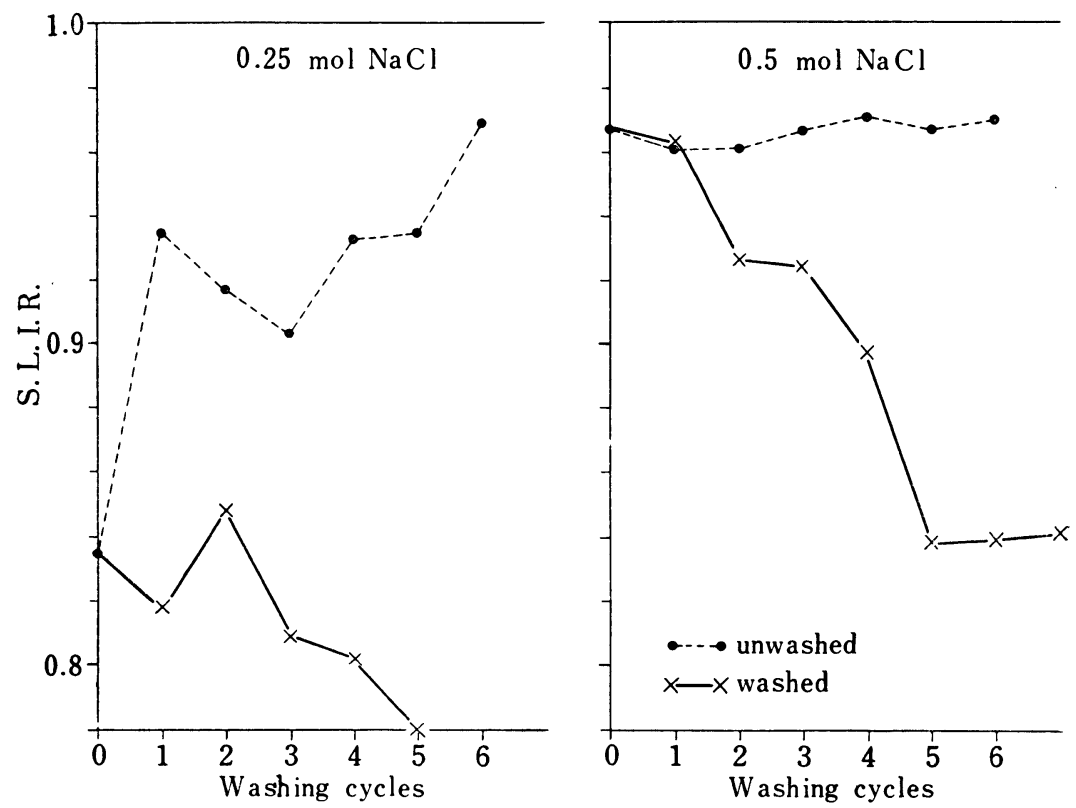

Fig. 5. S.L.I.R.-change of red cell suspension in variably concentrated saline after repeated washing with their media. 
as was pointed out already in the previous paper (Nakamura and Amada, 1958). A point which stands out clearly in the data is that the washing effect is enough to produce the conspicuous change in S.L.I.R. beyond the effect of time passing. Fig. 3 illustrates the results of another similar experiment of different human blood cells. The appearances of the curves are in close agreement with those in Fig. 1 except the increasing tendency of the last point.

Washing-Requirement of Red Cell for Minimal S.L.I.R. of the Suspension

The evidence presented above indicates that the washing-frequency-sequence of the S.L.I.R. of suspension of one blood is not the same with that of another
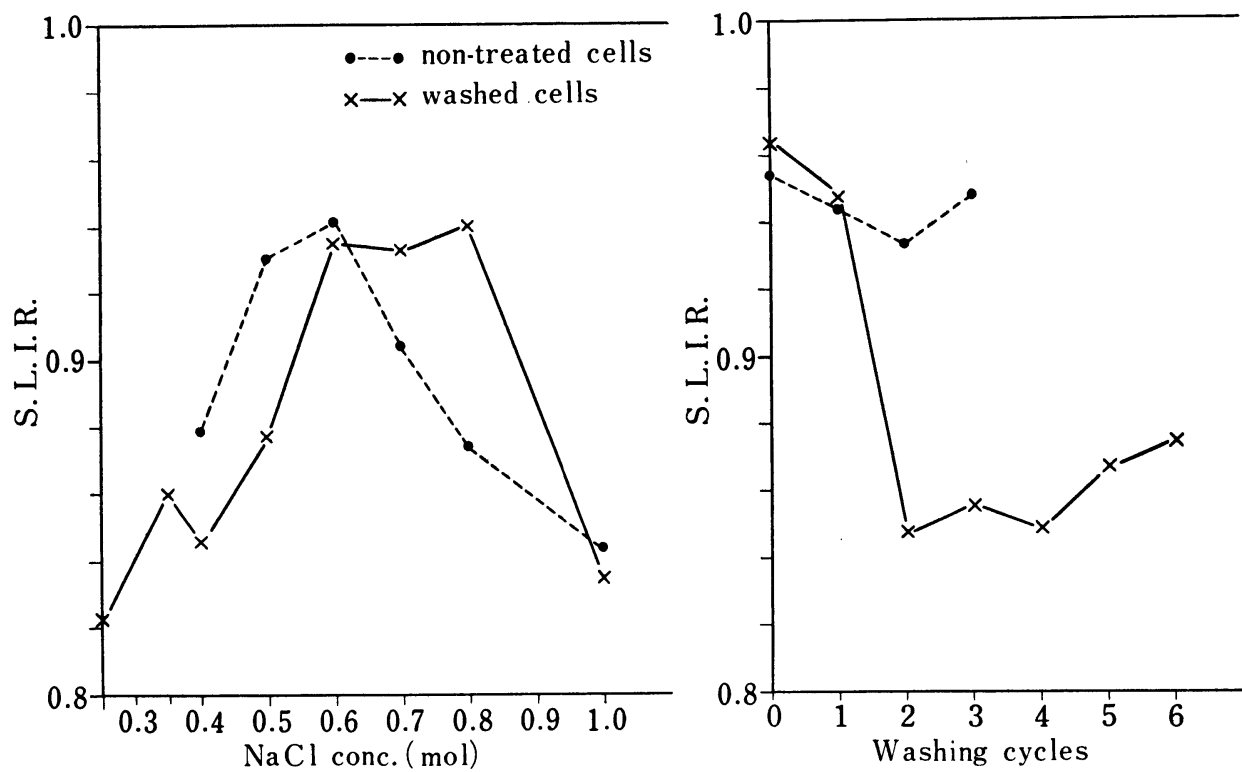

Fig. 6. (left) S.L.I.R. of washed red cell suspenșion in serialy diluted saline solution.

Fig. 7. (right) Influence of the serum in washing medium on S.L.I.R. of the suspension.

Complete line: washed with simple saline solution. Dotted line: washed with saline containg $0.5 \%$ of serum. Open circle: suspended in the saline containing $0.5 \%$ of serum after having been washed with simple saline solution.

person. Then this experiment was undertaken subjecting red cells to the intensive washing. The S.L.I.R. was estimated after each three washing cycles. The data obtained are shown in Fig. 4. The minimum of the S.L.I.R. appears after three washing cycles in this curve, and after that point the curve reverses again and continues to increase gradually, leaving finally behind the value of the original suspension. 


\section{S.L.I.R.-Change of Red Cell Suspension in Variably Concentrated Saline after Repeated Washings with Their Media}

Three sorts of suspension in the variably concentrated saline e.g., (a) $0.25 \mathrm{~mol} \mathrm{NaCl}$, in which the S.L.I.R. takes its minimum, (b) $0.5 \mathrm{~mol} \mathrm{NaCl}$, representing maximal S.L.I.R., (c) $0.8 \mathrm{~mol} \mathrm{NaCl}$, representing another minimal S.L.I.R., were tested. To make a control in strict meaning, series of unwashed suspension were subjected to the same centrifugation and resuspending agitation.

Fig. 5 shows that these mechanical treatments have no effect on the S.L.I.R. decrease, but rather have that of accelerating the increase. The long stride decrease of the S.L.I.R., as is the case with the suspension in $0.5 \mathrm{~mol} \mathrm{NaCl}$, is very impressive. The thorn apple-formed cells, although they may possess the crenation but almost perfectly symmetric, turn their shape to the smooth biconcave discs after five washing cycles, as if they were in the serum. Red cells in 0.8 mol saline adhered to each other and conglomerated to a clump after five minutes of centrifugation at $3,000 \mathrm{rpm}$, thus the subsequent observation was given up.

\section{S.L.I.R. of Washed Red Cell Suspension in Serially Diluted Saline}

The observation was carried out on the series of red cell suspension, containing $0.08 \mathrm{cc}$ of the four time washed red cells in $20 \mathrm{cc}$ of new saline. Fig. 6 demonstrate the gap between two S.L.I.R.- $\mathrm{NaCl}$ concentration-curves, the one that of experimental series and the another that of series for control, viz., the suspension containing unwashed red cells. Briefly saying, the former takes the situation shifted to the right compared with the control.

\section{Red Cell Washing by Saline Solution Containing Serum}

When the red cells are washed by saline, containing the serum to $5 \%$, the S.L.I.R. of the suspension does not change notably as is presented in Fig. 7. Red cells which have changed their shapes to discoid after having been washed five times by $0.5 \mathrm{~mol}$ saline, do no more retrace their step becoming spherous.

\section{Discussion}

Being suspended in artificial media, all red cells do not necessarily take the shape similar to each other. In these cases, if we desire to characterise quantitatively these shape of variety, we will have to practise many measurements on each cells and to arrange them statistically. It is too complicated to do so in routine works, and the data obtained in such a way are yet poorly objective. On the other hand, the estimation of S.L.I.R. is simple enough to complish in a few minutes and can provide a definite value concerning with the degree of morphologic asymmetry in the masse.

Investigating the change of S.L.I.R. and the microscopic photographs we have observed the way how the washing process, general procedure in the serological fields, effect on shape change and the duration of the effect, which is detectable when we resuspend these pretreated cells in saline of different concentration. As to the cause of these shape changes we can accept two factors, e.g., the change 
in $\mathrm{pH}$ and the removal of cell component. $\mathrm{pH}$ of the red cell gruel which was used in these experiments was 7.8 and that of the saline solution 5.8. Then the decrease of $\mathrm{pH}$ of the red cell suspension through the washing cycle is easily conceivable. Claudio, (1931) and Teitel-Bernard (1932) have observed that human red cells in saline media containing acetate buffers begin to crenate at $\mathrm{pH} 7.0$ when the $\mathrm{pH}$ is reduced towards the isoelectric point of $\mathrm{Hb}$, and the crenations persist until about $\mathrm{pH}$ 6.0, below which the cells are descoid until they begin to hemolyse at about $\mathrm{pH}$ 5.0. (quoted by Ponder, 1948). In spite of some discrepancy, existing between his technique and ours, his observation is very profitable to explain our data.

On the other hand the crystalbumin both in concomitant serum and of red cells (Hewitt, 1938; Furchgott, 1940; Furchgott and Ponder, 1940) will be washed away as well as lipoprotein, cholesterol and phospholipid (Lovelock, 1955). So that, it is still a matter of great importance to make clear the grade of the role which are played by them.

\section{SUMMARY}

1. Mechanical agitation of red cell suspension promote the sphering tendency of red cells and the increase of S.L.I.R. of the suspension (media: 0.25 and $0.5 \mathrm{~mol} \mathrm{NaCl}$ ).

2. When red cells in 0.25 or $0.50 \mathrm{~mol}$ saline were centrifuged down and were resuspended in a fresh medium of the same saline concentration, they increase the degree of asymmetry in shape. After several washing cycles they begin to follow the reverse course.

3. When red cells are washed by $0.5 \mathrm{~mol}$ saline, containing $5 \%$ of serum, only a slight shape-change is appreciable.

4. The cells which have become discoid after having been washed by $0.5 \mathrm{~mol}$ saline do not change easily their shape in saline containing $5 \%$ of serum.

5. The S.L.I.R.-NaCl concentration curve of washed red cells (by $0.5 \mathrm{~mol}$ $\mathrm{NaCl}$ ) is different from that of non-treated cells; the former takes the situation shifted to the right, to the direction of higher concentration, as compared with the latter.

\section{REFERENCES}

Fruchgott, R. F. (1940): Disk-shape transformation in mammalian red cells. J. Exp. Biol., 17, 30-44.

FURCHGOTT, R. F. \& PoNdER, E. (1940): Disk-shape transformation in mammalian red cells. II. The nature of the anti-sphering factor. J. Exp. Biol., 17, 118-127.

LoveLoCK, J. E. (1955): The physical instability of human red blood cells. Biochem. J., $60,692-696$.

MIYAKE, H. (1955): Studies on the correlation between the medium and the shape of erythrocyte. III. Effect of the previous washing of red blood cells with the saline solution on the shape of the non-nucleated erythrocyte in the saline solutions of various concentrations. Tokushima J. Exp. Med., 2, 63-65. 
NAKamura, W. \& Amada, Y. (1958): Studies on the streaming transparency of red blood cell suspension. IV. Streaming-light-interruption-ratio (S.L.I.R.) of erythrocyte suspension and condition of its determination. Jap. J. M. Sc. Biol., 11, 153-160.

Nakamura, H. \& Kurada, K. (1936): Mécanisme de l'hémolyse au point de vue de la masse active dans le système hétérogène. Keijo J. Med., 7, 20-97.

PoNDER, E. (1948) : Hemolysis and related phenomena, Grune \& Stratton, New York. Claudio, P. (1931): Bull. Soc. Ital. Biol. Sper., 6, 43.

HewitT, L. F. (1540): Biochem. J., 32, 27.

Teitel-Bernard, A. (1934): Arch. Roumain. Path., 5, 389.

Above three articles are cited from a text, Ponder, E. (1948): Hemolysis and related phenomena, Grune \& Stratton, New York. 